\title{
Effects of brassinosteroid application on seed germination of Norway spruce, Scots pine, Douglas fir and English oak
}

\author{
Ivan Kuneš, Martin Baláš, \\ Rostislav Linda, Josef Gallo, \\ Olga Nováková
}

\begin{abstract}
We tested the influence of a synthetically-produced brassinosteroid compound (2a,3a,17Btrihydroxy-5a-androstan-6-one) on seed germination in Norway spruce, Scots pine, Douglas fir and English oak. Before germination, 400 seeds of each species were steeped in a brassinosteroid solution and then placed for germination in a growth chamber under (i) optimal humidity and (ii) temporary drought stress (except for oak). Drought stress significantly reduced the germination capacity and germination rate in the control treatments of Norway spruce, Scots pine and Douglas fir. Nonetheless, the application of brassinosteroid significantly reduced the drought-stress effects in seeds of Norway spruce and Scots pine. The drought-stressed Douglas fir did not respond positively to the brassinosteroid application. English oak was germinated only under the optimal humidity regime and no differences in germination were detected between the control and brassinosteroid-treated acorns.
\end{abstract}

\section{Keywords: Plant Hormones, Germination Percentage, Germination Rate, Picea abies, Pseudotsuga menziesii}

\begin{abstract}
Introduction
Rapid, synchronous full-capacity germination is an important component of commercial seedling production in forestry (Liu et al. 2013). Seeds germinated over a protracted period will generate seedlings with different requirements across the crop, thus the growing measures will be inevitably ill-suited for part of the seedlings ( $\mathrm{Hi}$ manen \& Nygren 2014). Germination problems in nursery may lead to a reduction in quality of the resulting plants and to an increase in length of the production cycle (O'Reilly \& Doody 2006) or may even result in a loss of part of the nursery crop.

Seed germination problems are often related to adverse microclimatic conditions. Moisture availability after sowing is one of the most important factors affecting seed germination in the nursery (O'Reilly \& Doody 2006). However, a full control of the soil moisture is not always possible (e.g., after direct seeding on a forest site or even in open outdoor nursery beds), thus drought stress may occur. Our hypothesis was that a pre-sowing application of chosen brassi-
\end{abstract}

nosteroid compounds might improve germination parameters of seeds subjected to drought stress.

Brassinosteroids (BRs) are a group of plant hormones that are important regulators of a number of the plant physiological processes (Krishna 2003, Bajguz \& Hayat 2009). They can interact with other hormones as well as with environmental stimuli (Sasse 1997). The first BR was isolated in 1979 from rapeseed (Brassica napus L.) pollen. At that time, $40 \mathrm{mg}$ of the active substance was extracted from $40 \mathrm{~kg}$ of pollen (Grove et al. 1979). The discovery of BRs promoted an intensive research on these plant hormones (Choudhary et al. 2012). Nowadays, around 70 different BR-compounds have been successfully isolated from plants, mostly in free form, but also conjugated to sugars and fatty acids (Bajguz 2007, Bajguz \& Hayat 2009). BRs structure is closely related to animal steroid hormones (Clouse 2002, Krishna 2003). They occur in many plant species (Sasse 1997, Zullo \& Kohout 2004) and are present in various parts of the plant, such as pollen,

$\square$ Faculty of Forestry and Wood Sciences, Czech University of Life Sciences Prague, Kamýcká 129, 16521 Praha 6 - Suchdol (Czech Republic)

@ Ivan Kuneš (kunes@fld.czu.cz)

Received: Jan 28, 2015 - Accepted: Jun 05, 2016

Citation: Kuneš I, Baláš M, Linda R, Gallo J, Nováková O (2016). Effects of brassinosteroid application on seed germination of Norway spruce, Scots pine, Douglas fir and English oak. iForest 10: 121-127. - doi: 10.3832/ifor1578-009 [online 2016-10-02]

seeds, leaves, flowers (Rönsch et al. 1993), roots (Kim et al. 2010) and also in insect galls (Yokota et al. 1982). Their content is commonly higher in young and growing plant tissues than in older mature tissues (Clouse 2002).

BRs are able to influence plant growth and cell division even at very low concentrations (Ikekawa \& Takatsuto 1984), thus affecting growth performances. BRs are also able to promote plant resistance to pathogens and diseases (Wang 2012, Ali et al. 2013), as well as various stress factors (Müssig et al. 2005, Divi et al. 2010). Moreover, BRs can influence plants' architecture, flowering and shedding of leaves (Gudesblat \& Russionova 2011). The positive effects of BRs on seed germination ( $\mathrm{Li}$ et al. 2005, Kartal et al. 2009) provided an important incentive to conduct this study.

Up to now, the applied research on BRs was conducted mainly in agriculture (see Choudhary et al. 2012 for a review). Research aimed at evaluating the potential of these phytohormones in forestry are rather sporadic (Li et al. 2005), and almost missing on European forest tree species.

A new BR-compound ( $2 \alpha, 3 \alpha, 17 \beta$-trihydroxy-5a-androstan-6-one) patented in 2003 (Kohout et al. 2003) has a production cost markedly lower than that of many natural BRs. The aim of the paper is to assess the effects of this new BR-compound on seed germination of four commercially important forest tree species (Podrázský et al. 2014, Remeš \& Zeidler 2014). Its effects were investigated under conditions of optimal humidity and temporary stress induced by short-term drought during early germination. 
Tab. 1 - Characteristics of the seed lots used in the present study. (1): Based on climatic characteristics of the forest vegetation (alti tudinal) zones of the original seed sources; (2): western Bohemia. (n/a): not available.

\begin{tabular}{lcccc}
\hline Species & Douglas fir & Scots pine & Norway spruce & English oak \\
\hline Code of seed source & SIA-473341 & CZ-3-3-BO-79-6-2-P & CZ-2-2B-SM-3735-6-3-P & CZ-1-2C-DB-388-6-3-P \\
\hline National seed lot code & CZ/9999/19/2011 & CZ/3206/6/2007 & CZ/3204/1/2010 & CZ/3201/1/2009 \\
\hline Seed ripened & 2009 & 2006 & 2009 & 2009 \\
\hline Seed source location & $\begin{array}{c}\text { USA; } \text { Washington, } \\
\text { Snoqualmie }\end{array}$ & $\begin{array}{c}\text { Czech Republic, } \\
\text { WB }^{2} \text {, Plzen }\end{array}$ & $\begin{array}{c}\text { Czech Republic, } \\
\text { WB }^{2} \text {, Plzen }\end{array}$ & $\begin{array}{c}\text { Czech Republic, } \\
\text { WB }\end{array}$ \\
& $\mathrm{n} / \mathrm{a}$ & $7.5-8.0$ & $6.5-7.5$ & $6.5-7.5$ \\
\hline Mean annual temperature $\left({ }^{\circ} \mathrm{C}\right)^{1}$ & $\mathrm{n} / \mathrm{a}$ & $600-650$ & $650-700$ & $650-700$ \\
\hline Mean annual precipitation $(\mathrm{mm})^{1}$ & 10.175 & 7.137 & 7.743 & $\mathrm{n} / \mathrm{a}$ \\
\hline Weight of 1000 pure seeds $(\mathrm{g})$ & 86530 & 123580 & 97172 & $\mathrm{n} / \mathrm{a}$ \\
\hline Number of pure live seeds per $1 \mathrm{~kg}$ & & & & \\
\hline
\end{tabular}

\section{Material and methods}

Tab. 1 summarizes the main information on the seed lots investigated in this study, including the following species: Douglas fir (Pseudotsuga menziesii [Mirbel] Franco), Scots pine (Pinus sylvestris L.), Norway spruce (Picea abies [L.] Karst.) and English oak (Quercus robur L.). Prior to the launch of the experiment in April 2011, conifer seeds were stored in vacuum-sealed plastic bags at $2-3.5{ }^{\circ} \mathrm{C}$ in the dark. For coniferous species, no cold stratification was conducted before the start of the experiment. No detailed information was available on the acorn storage. Considering the year of ripening (2009), they were probably stored frozen at about -1 to $-3{ }^{\circ} \mathrm{C}$ (Suszka et al. 1996, Hoffmann et al. 2007). The acorns were supplied in moist sand. In the laboratory, the sand was washed off; the acorns were put into water and those floating were discarded. Immediately before the experiment, random samples of seeds were established for each species after hand-mixing of seeds; thus germination tests were conducted using pure seed lots.

For each species, two different treatments were chosen: (i) the control; (ii) the brassinosteroid treatment. Except for English oak, seeds were subjected to two humidity regimes: (i) the optimal humidity regime (unstressed regime); and (ii) the drought-stressed regime (Tab. 2).

Before germination, the seeds were sterilized in sodium hypochlorite ( $1 \%$ solution) for $10 \mathrm{~min}$ and then thoroughly rinsed. For
English oak, a third of each acorn was cut off at the cup scar end and the pericarp was removed in order to overcome seed dormancy (Bonner \& Vozzo 1987), according to the Czech's and International seed testing rules (CNI 2006, ISTA 2015). Subsequently, the BR-treated seeds were immersed into BR solution ( $\left.0.1 \mathrm{mg} \mathrm{l}^{-1}\right)$ for 48 hours at room temperature $\left(20^{\circ} \mathrm{C}\right)$. The brassinosteroid $\quad(2 \alpha, 3 \alpha, 17 \beta$-trihydroxy-5a-androstan-6-one) was synthesized by PHPchem Co. Ltd. (Neratovice, Czech Republic). Similarly, the control seeds were immersed into distilled water for 48 hours at $20^{\circ} \mathrm{C}$. Germination tests on conifer species were conducted in a growth chamber, while the oak acorns were tested in a thermostatic room. The conifer seeds were germinated on two layers of filter paper $\left(50 \mathrm{~g} \mathrm{~m}^{-2}\right)$ soaked by distilled water in transparent plastic vessels $6.5 \times 9 \times 3.5 \mathrm{~cm}$. Acorns were placed about $2 \mathrm{~cm}$ deep inside a $4 \mathrm{~cm}$-thick layer of sterilized sand in small drained racks (40 $\times$ $30 \times 10 \mathrm{~cm}$ ) that were lined with propylene water-permeable mulch $\left(50 \mathrm{~g} \mathrm{~m}^{-2}\right)$ at the bottom and on the sidewalls. As for Douglas fir, Scots pine, and Norway spruce, the germination process consisted of 21 oneday cycles ( $24 \mathrm{hrs}$ ), composed of dark periods of 16 hours at $20^{\circ} \mathrm{C}$ and light periods of 8 hours at $30{ }^{\circ} \mathrm{C}$. Light at about 3000 lux was provided by means of cool white fluorescent tubes. The acorns (English oak) were germinated only in darkness at $20{ }^{\circ} \mathrm{C}$ in the moist sand for 28 days.

In the (unstressed) optimal humidity re-
Tab. 2 - Design of the experiment. (Code): treatment-regime combination code.

\begin{tabular}{lllccc}
\hline Species & Treatment & Regime & Code & $\begin{array}{c}\text { Seeds } \\
\text { (n) }\end{array}$ & $\begin{array}{c}\text { Replications } \\
\text { (n) }\end{array}$ \\
\hline Douglas & control & optimal humidity & CO & 400 & 8 \\
fir & & drought-stressed & CS & 400 & 8 \\
& brassinosteroid & optimal humidity & BO & 400 & 8 \\
& & drought-stressed & BS & 400 & 8 \\
Scots & control & optimal humidity & CO & 400 & 8 \\
pine & & drought-stressed & CS & 300 & 6 \\
& brassinosteroid & optimal humidity & BO & 400 & 8 \\
& & drought-stressed & BS & 200 & 5 \\
Norway & control & optimal humidity & CO & 400 & 8 \\
spruce & & drought-stressed & CS & 400 & 8 \\
& brassinosteroid & optimal humidity & BO & 400 & 8 \\
& & drought-stressed & BS & 400 & 8 \\
English & control & optimal humidity & CO & 400 & 4 \\
oak & brassinosteroid & optimal humidity & BO & 400 & 4 \\
\hline
\end{tabular}

gime applied to conifer species, the relative air humidity ranged between $90-92 \%$ inside the testing vessels (Tab. 2). The seeds were placed on water-soaked filter paper and the vessels were cupped with lids. Contrastingly, vessels in the drought-stressed regime were left uncapped and exposed to conditions with $58-62 \%$ relative air humidity for 48 hours (two one-day cycles) at the beginning of the germination. Subsequently, the filter paper was re-soaked and the drought-stressed seeds were sprayed with distilled water; vessels were then cupped and the regime was shifted to that of the optimal humidity. English oak seeds were excluded from the drought-stressed regime. The acorns were placed in moist sand (about $12-15 \%$ of humidity by weight), which avoided any temporary drought.

To achieve uniformity of conditions during the course of the experiment, the germination process of all tested species was ran simultaneously. The full experimental design including the numbers of seeds and replications for each treatment-regime combination is described in Tab. 2. Each replication was placed in a separate vessel (conifers) or rack (English oak).

For the tested conifers, germinated seeds were counted on the $7^{\text {th }}, 14^{\text {th }}$, and $21^{\text {st }}$ day after the start of germination. For oaks, an additional count was taken on the $28^{\text {th }}$ day. The duration of the drought-stressing regime (48 hours) in the stressed treatments was included in the total duration of germination.

Conifer seeds were considered completely germinated when their radicle was four times the length of the seed coat and no abnormalities were apparent. Acorns were scored as germinated when both radicle and shoot exhibited growth and leaves started to develop. The germinated seeds were removed from the vessels/ racks. For the purpose of this study, the germination capacity of filled seeds was defined as the percentage of seeds that had germinated during the test (i.e., over a period of 21 and 28 days for conifers and oak, respectively). The germination energy of filled seeds was defined as the percentage of the completely germinated seeds recorded on the $7^{\text {th }}$ day after the beginning of the experiment. The numbers of empty and dead seeds were determined after the 
test completion by cutting open the seeds that failed to germinate.

To compare the percentage of germinated seeds between the treatment-regime combinations, the test of homogeneity of binomial distributions was applied by multiple comparisons $(\alpha=0.05)$. Differences in the relative germination frequency among treatments were tested using the formula described by Agresti et al. (2008), which was originally used for calculating confidence intervals of differences in probabilities. Using this approach, the null hypothesis about equality of two compared binomial proportions is rejected when (eqn. 1):

$$
\frac{\left|\hat{p}_{i}-\hat{p}_{j}\right|}{s e} \cdot \sqrt{2} \geq Q_{T}(\alpha)
$$

where $Q_{\mathrm{T}}(\alpha)$ is the critical value of Studentized range distribution for the chosen significance level and an infinite number of degrees of freedom, while $\hat{p}_{\mathrm{i}}$ and $\hat{p}_{\mathrm{i}}$ are the probabilities of success (germination) in the compared treatment-regime combinations, which were computed as follows (eqn. 2):

$$
\hat{p}_{i}=\frac{\left(y_{i}+1\right)}{\left(n_{i}+2\right)}, \hat{p}_{j}=\frac{\left(y_{j}+1\right)}{\left(n_{j}+2\right)}
$$

where $y_{\mathrm{i}}$ and $y_{\mathrm{i}}$ are the numbers of successes (completely germinated seeds), $n_{\mathrm{i}}$ and $n_{\mathrm{b}}$ are the numbers of observations (number of all seeds within a treatmentregime combination that were subjected to the germination test minus number of empty seeds within the respective treatment-regime combination) and se was calculated as (eqn. 3):

$$
s e=\sqrt{\frac{\hat{p}_{i}\left(1-\hat{p}_{i}\right)}{n_{i}+2}+\frac{\hat{p}_{j}\left(1-\hat{p}_{j}\right)}{n_{j}+2}}
$$

Seed germination rate $(G R)$ was calculated for each species as the sum of values obtained by dividing the weekly percentages of completely germinated filled seeds by the number of days the seeds had been left in the growth chamber, using the following formula (adapted from Maguire 1962 - eqn. 4):

$$
G R=\left(\frac{G P_{1}}{\Delta t_{1}}+\frac{G P_{2}}{\Delta t_{2}}+\ldots+\frac{G P_{n}}{\Delta t_{n}}\right)
$$

where $n$ is the week of counting, $G P_{\mathrm{n}}$ is the percentage of completely germinated filled seeds in the $n$-th week, $\Delta t_{\mathrm{n}}$ is the number of days elapsed from the beginning of the experiment $(7,14,21$ days, and 28 for oak only).

The Kruskal-Wallis test $(\alpha=0.05)$ was applied to test for differences in germination rates among treatment-regime combinations in Norway spruce, as the data were not normally distributed. Two-way analysis of variance was used to compare germination rates of Scots pine and Douglas fir, where the first factor was the treatment (control vs. brassinosteroid) and the second one was regime (optimal vs. drought-

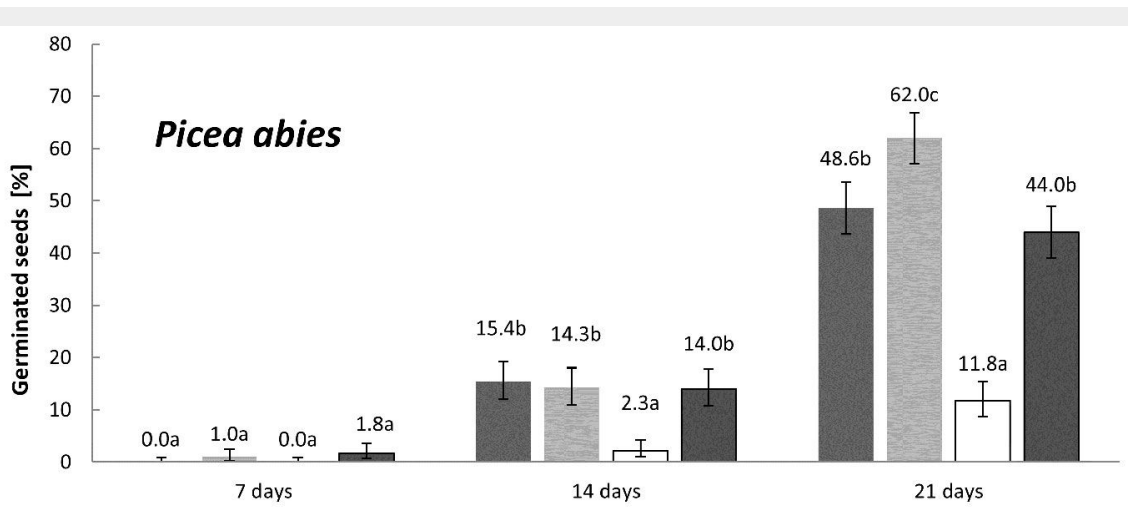

m CO - control optimal $\equiv$ BO - brassinosteroid optimal $\square$ CS - control stressed $\square$ BS - brassinosteroid stressed

Fig. 1 - Cumulative percentage of germinated Norway spruce seeds in the control and brassinosteroid treatment recorded 7,14 , and 21 days after the beginning of germination under optimal humidity or drought-stressing regime. Error bars represent $95 \%$ confidence intervals. Different letters indicate significant differences $(p<0.05)$ between the means.

stressed). For English oak, the Student's $t$-test was applied $(\alpha=0.05)$ to test for differences between treatments.

\section{Results}

\section{Norway spruce}

The germination of untreated Norway spruce seeds was significantly affected by the exposure to the drought stress (Fig. 1). The results also showed a markedly positive effect of brassinosteroids on germination under drought-stressing conditions. At the end of the germination process, seeds under drought-stress treated with the brassinosteroid (BS combination) showed almost four-times higher germination (cumulative germination percentage on the $21^{\text {st }}$ day) than the control seeds exposed to drought stress (CS combinations). The application of the brassinosteroid also significantly increased the germination capacity under optimal humidity regime.

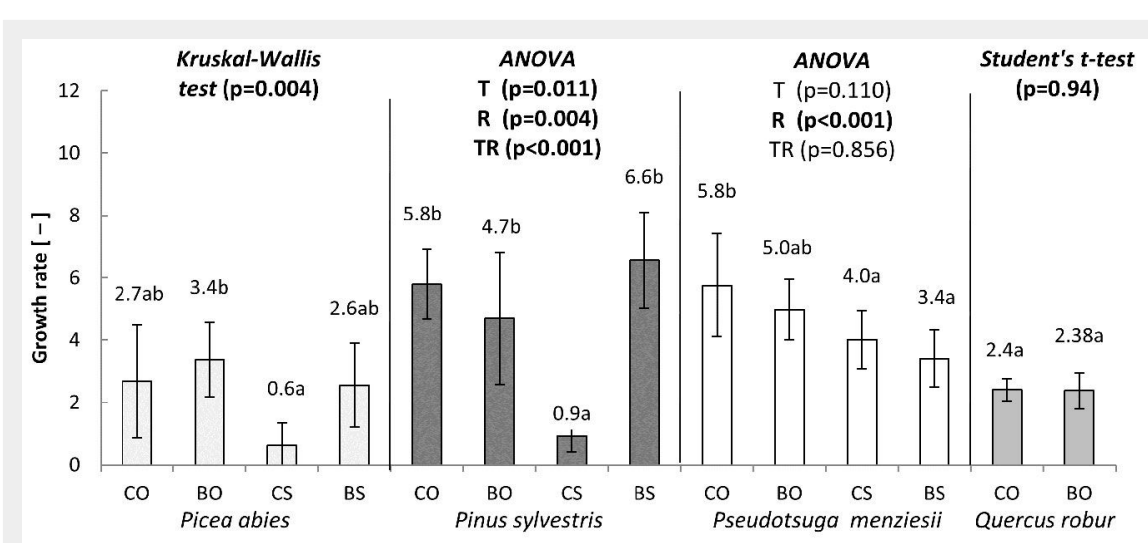

CO - control optimal BO - brassinosteroid optimal CS-control stressed BS- brassinosteroid

Fig. 2 - Growth rates calculated from the germination tests carried out for a period of 21 days in conifers and 28 days in English oak. The statistical procedures applied and the $p$-values obtained are reported for each species. $(T)$ : treatment; $(R)$ : regime; (TR): $T \times R$ interaction. Different letters following mean values denote significant differences $(p<0.05)$ after the multiple comparisons of treatment-regime combinations within each species. Error bars represent the standard deviation. 


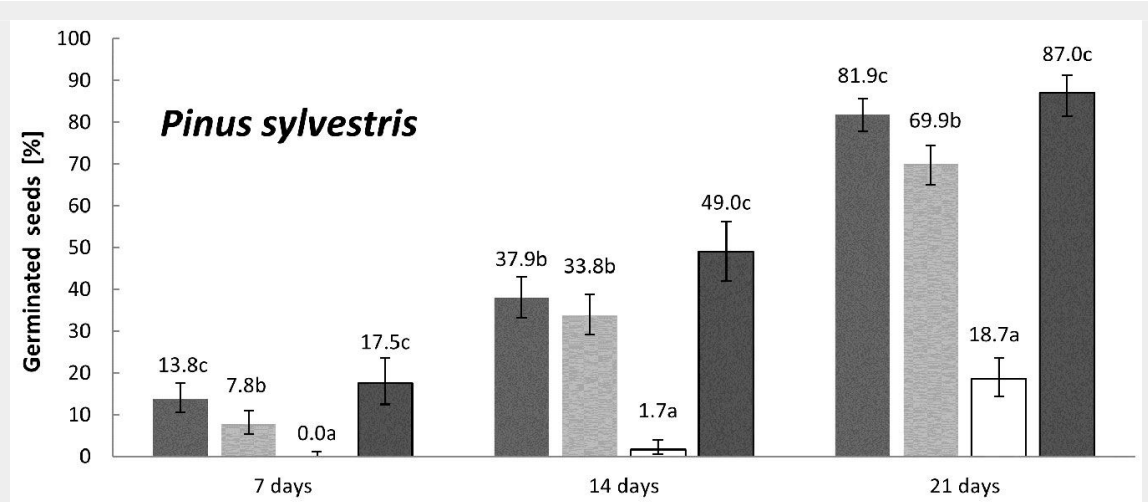

CO - control optimal $=\mathrm{BO}$ - brassinosteroid optimal $\mathrm{\square CS}$ - control stressed $\square \mathrm{BS}$ - brassinosteroid stressed

Fig. 3 - Cumulative percentage of germinated Scots pine seeds in the control and brassinosteroid treatment recorded 7,14 , and 21 days after the beginning of germination under optimal humidity or drought-stressing regime. Error bars represent $95 \%$ confidence intervals. Different letters after the values indicate significant differences between the means $(p<0.05)$.

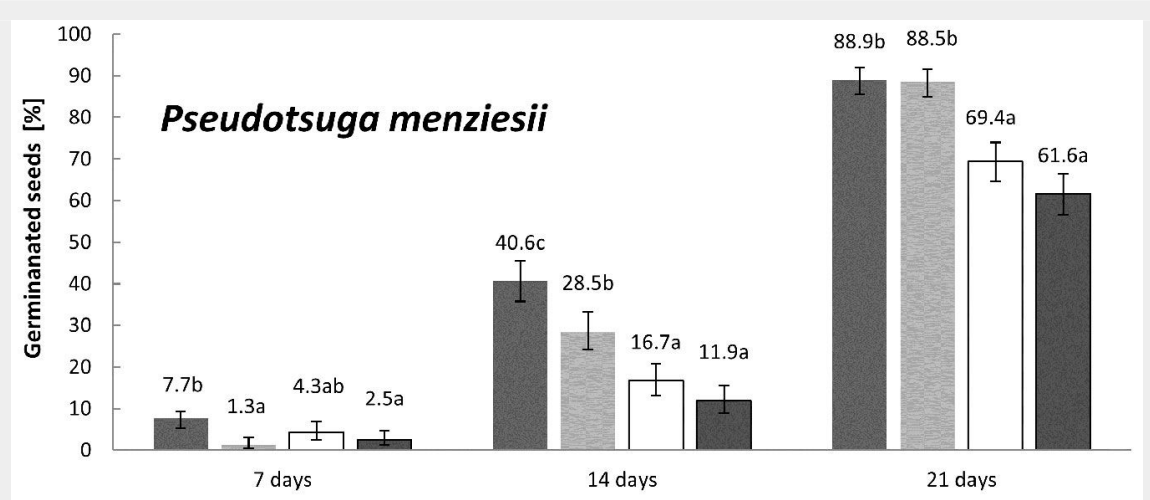

a CO - control optimal 트 $\mathrm{BO}$ - brassinosteroid optimal $\square \mathrm{CS}$ - control stressed $\square \mathrm{BS}$ - brassinosteroid stressed

Fig. 4 - Cumulative percentage of germinated Douglas fir seeds in the control and brassinosteroid treatment recorded 7,14 , and 21 days after the beginning of germination either under optimal humidity or drought-stressing regime. Error bars represent $95 \%$ confidence intervals. Different letters indicate significant differences between the means $(p<0.05)$.

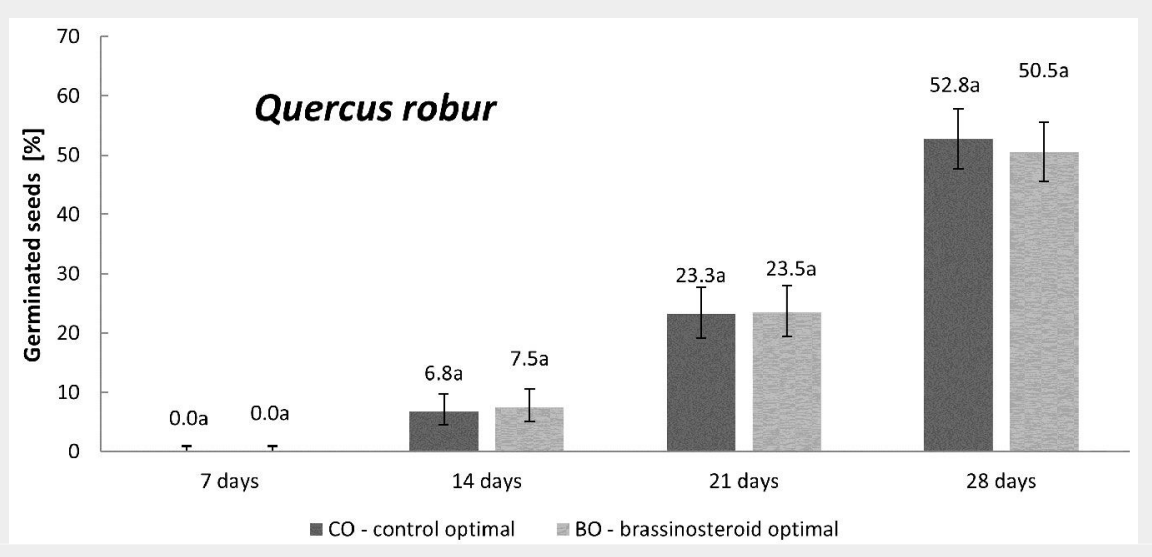

Fig. 5 - Cumulative percentage of germinated English oak seeds in the control and brassinosteroid treatment recorded 7, 14, 21 and 28 days after the beginning of germination under the optimal humidity regime. Error bars represent $95 \%$ confidence intervals. Different letters indicate significant differences $(p<0.05)$ between the means after Student's t-test.

Interestingly, and in contrast to Norway spruce, pine seeds treated with the brassinosteroid under optimal humidity regime
(BO) showed significantly lower germination capacity (by $12 \%$ ) than the control seeds germinated under optimal humidity regime (CO).

The germination rate of Scots pine seed lots was significantly affected both by the treatment $(p=0.011)$ and the regime $(p=$ $0.004)$, as well as by their interaction ( $p<$ $0.001)$. The germination rate of the BRtreated seeds under optimal humidity regime (BO) was reduced in comparison with the control seeds germinated under optimal humidity regime (CO). Under drought stress, however, the applied BR significantly expedited seed germination. The germination rate of the droughtstressed BR-treated seeds (BS) was almost comparable to the germination rate recorded in the $\mathrm{CO}$, whereas the germination rate of the control seeds under drought stress (CS) was more than 6 times lower than that of the control seeds incubated under optimal humidity regime (CO).

\section{Douglas fir}

The impact of drought stress on Douglas fir germination was obvious and significant (Fig. 4). However, it was markedly less pronounced than in the case of Norway spruce and Scots pine (Fig. 1, Fig. 3, Fig. 4).

The bar chart in Fig. 2 suggests that the effect of BR application on Douglas fir germination rate was rather inhibitory (regardless of the humidity regime considered), though not significant $(p=0.11)$. On the other hand, the drought stress significantly inhibited the germination rate $(p<0.001)$ in Douglas fir. No interaction between the treatment and regime was found ( $p=$ o.86). The highest germination rate was detected for the control seeds germinated under optimal humidity regime (CO). The $\mathrm{BO}, \mathrm{CS}$ and BS treatment-regime combinations showed lower values than CO (100\%) by $13.8 \%, 31 \%$ and $41.4 \%$, respectively.

\section{English oak}

English oak was incubated only under the optimal humidity regime. The application of brassinosteroid did not affect the germination of acorns. The proportion of germinated seeds in the control and BR treatment remained almost equal in all the four counting dates (Fig. 5). Moreover, the germination rate of acorns (Fig. 2) did not differ between the control and BR treatment $(p=0.94)$.

\section{Discussion}

We tested the effects of $2 \alpha, 3 \alpha, 17 \beta$-trihydroxy-5a-androstan-6-one on seed germination of three native and one introduced forest tree species commonly used in Central-European forest management. The effects of the brassinosteroid application on seed germination (except for oak) were examined in combination with temporary drought stress, as could often occur after direct seeding at a forest site or in small forest nurseries with limited access to artificial irrigation.

A positive effects of $B R s$ on seed germination has been reported for various species in the literature. For example, Leub- 
ner-Metzger (2001) suggested that BR treatment promoted growth potential of embryos in tobacco (Nicotiana tabacum L.) seeds. Treating barley (Hordeum vulgare L.) seeds with BRs accelerated germination and development of primary and seminal roots (Kartal et al. 2009) as well as growth of juvenile seedlings in the greenhouse and growth chamber (Gregory 1981). A stimulating effect of BRs on seed germination was also documented in Arabidopsis Heinh. by Steber \& McCourt (2001), who proposed that BRs play a role in antagonizing seed dormancy. Yamaguchi et al. (1987) reported that brassinosteroids improved germination of aged rice (Oryza sativa L.) seeds and seedlings emergence. Srivastava et al. (2011) described a positive effect of BRs on germination of moong bean (Phaseolus aureus Rox.).

As regards with the effects of BRs on plants under stressing conditions, Wilen et al. (1995) found only a slight increase in freeze tolerance (by $3-5^{\circ} \mathrm{C}$ ) of smooth bromegrass (Bromus inermis Leyss) cell cultures treated with BRs, but cell viability after exposure to high temperature stress was markedly enhanced by the treatment. Dhaubhadel et al. (1999) reported that oilseed rape (Brassica napus) and tomato (Solanum lycopersicum) seedlings grown in the presence of 24epibrassinolide were significantly more tolerant to a lethal heat treatment than the control seedlings grown in the absence of the BR compound. Vardhini \& Rao (2003) reported that brassinosteroids were able to reverse inhibitory effect of osmotic stress induced by $20 \%$ Polyethylene Glycol (simulating drought stress) on germination of sorghum (Sorghum vulgare Pers.) seeds. The application of brassinosteroids to rice (Oryza sativa L.) seeds reduced the impact of salt stress in the initial period after germination (Anuradha \& Rao 2003). The addition of BR significantly alleviated the negative impacts of $\mathrm{NaCl}$ on germination of cucumber (Cucumis sativus L.) seeds (Wang et al. 2011). Drought-stress tolerance of wheat (Triticum aestivum L.) induced by brassinosteroids was reported by Sairam (1994). Despite the stressing conditions mentioned above are not directly comparable, and the methods used in testing seed germination often differ among studies, it has been suggested that drought, high temperature and salinity stresses are often interconnected and may induce similar cellular damage (Bajguz \& Hayat 2009).

The effect of BRs application on seeds of forest tree species has been scarcely studied. Li et al. (2008) investigated the effect of BR treatments on one-year-old seedlings of black locust (Robinia pseudoacacia L.). Their results suggest that the BR treatment could reduce water stress and enhance drought tolerance. They achieved the best results using a solution with $B R$ concentration of $0.2 \mathrm{mg} \mathrm{l}^{-1}$. Li et al. (2005) stated that soaking the seeds in a brassinolide (a natural brassinosteroid) solution ( $\left.0.4 \mathrm{mg} \mathrm{l}^{-1}\right)$ for
2 days improved the germination rate $(G R)$ and germination energy $(G E)$ of tree-ofheaven (Ailanthus altissima [Mill.] Swingle) by 17.6 and $18.7 \%$, respectively. According to the study by Li et al. (2002), $G R$ and $G E$ increased by $23.1 \%$ and $14.9 \%$, respectively, using a solution of natural brassinolide at $0.05 \mathrm{mg} \mathrm{I}^{-1}$ in Chinese red pine (Pinus tabulaeformis Carr.), while in black locust (Robinia pseudoacacia L.) the use of a solution at $0.01 \mathrm{mg} \mathrm{l}^{-1}$ increased $G R$ and $G E$ by $10.9 \%$ and $15.9 \%$, respectively.

In this study, we tested $0.1 \mathrm{mg} \mathrm{l}^{-1}$ concentration of the BR compound on seeds of four forest tree species. The results differed significantly depending on the species and humidity regime. For Norway spruce and Scots pine, its effects under the optimal humidity regime were less distinct than under drought stress. More specifically, differences in germination capacity were found also under optimal humidity, indicating a favorable effect of the BR treatment in Norway spruce, but a detrimental effect in the case of Scots pine. However, under drought stress, the effect of BR treatment in comparison with the control were decidedly more evident. For both Norway spruce and Scots pine, the effect of BR treatment under drought stress were positive in terms of both germination capacity (Fig. 1, Fig. 3) and germination rate (Fig. 2). For Scots pine, such effect was slightly negative under optimal humidity whilst definitively positive under drought stress (Fig. 3, Fig. 2). As for English oak seeds, the germination of the control and BR-treated seeds did not differ under optimal humidity (Fig. 5, Fig. 2). In general, these results are in accordance with the findings by Krishna (2003) who suggested that the favorable effect of brassinosteroids on plant germination and growth is more obvious under stress and less evident under optimal conditions.

As regards Douglas fir, seed germination seems to be affected more by the humidity regime than by the BR treatment. Indeed, a slightly negative response to the $B R$ treatment was found for this species, though this was not statistically supported. Nonetheless, the germination rate of the BR-treated seeds was detectably lower in comparison to the control, regardless of the humidity regime (Fig. 2). Similarly, the BR treatment of Douglas fir showed a noticeably lower (though not significant) germination capacity under drought stress than the control (Fig. 4). In this context, it is worth to notice that Douglas fir was the least drought-affected species among all those considered.

The concentration of $B R$ in the solution used for soaking the seeds could partly explain the different responses observed in this study among the species considered. Indeed, seeds of different species may react differently to similar BR concentrations. Germination of Ailanthus altissima was most effectively promoted with $0.4 \mathrm{mg} \mathrm{l}^{-1} \mathrm{BR}$ concentration (Li et al. 2005), while Robinia pseudoacacia and Pinus tabulaeformis showed the best germination at 0.1 and $0.05 \mathrm{mg} \mathrm{l}^{-1}$, respectively ( $\mathrm{Li}$ et al. 2002), and a BR concentration as low as $0.01 \mathrm{nM}\left(\sim 0.005 \mathrm{mg} \mathrm{l}^{-1}\right)$ was most effective to improve germination and seedling growth of tomato under phenanthrene stress (Ahammed et al. 2012). Furthermore, the different history of the different seed lots used in this study (in terms of age, storage conditions, etc.) could also have played a role in the different responses among species to the BR treatment.

The low germination of unstressed Norway spruce seeds in our study was probably the result of dormancy after storage, as such species usually show better germination (Nowakowska \& Rakowski 2002, Hoffmann et al. 2007). This assumption is supported by the relatively high percentage of viable ungerminated seeds at the end of the germination test $(47 \%$ and $33 \%$ for the $\mathrm{CO}$ and $\mathrm{BO}$ treatment-regime combinations, respectively). The cold stratification (moist chilling) might have increased the germination capacity (Youngblood \& Safford 2008). Moreover, the illumination intensity during the experiment could also have played a role in determining the low germination observed for Norway spruce seeds (Leinonen \& Rita 1995). However, this does not impair the results of the comparison between the BR-treated and control Norway spruce seeds, as seeds in both treatments were sampled from the same seed lot and were subjected to the same humidity regimes.

The germination capacity of the tested (unstressed and BR-untreated) Scots pine seeds showed values similar to those reported in other studies from Central Europe (Kamra \& Simak 1968, Hoffmann et al. 2007). However, the cold stratification of seeds (moist chilling) might increase the germination capacity of the species (Krugman \& Jenkinson 2008). As for Douglas fir, the germination capacity and the germination energy of unstratified seeds recorded in this study correspond to data presented by Houšková \& Martiník (2015). The low germination rate of unstratified Douglas fir seeds has been well documented (Edwards \& El-Kassaby 1995). Our results suggest that the BR treatment cannot substitute the cold stratification treatment in conifer species (Hoffmann et al. 2007, Youngblood \& Safford 2008, Houšková \& Martiník 2015). The lower germination capacity of English oak seeds might have been the result of worse quality of the seed lot used, as well as of the duration and regime of storage.

In general, our study suggests that the BR application can reduce the impact of drought stress on seed germination of Norway spruce and Scots pine. However, these preliminary findings should be verified on a large number of seed lots. Cold stratification (moist chilling) might be desirable to achieve better physiological homogeneity of seed lots, although this pre-treatment is 
not prescribed for Norway spruce and Scots pine by Czech technical rules (CNI 2006) before seed testing.

\section{Conclusions}

Drought stress significantly reduced germination capacity and germination rate of the tested seed lots of Norway spruce, Scots pine and Douglas fir. The application of BR in our study was effective in counteracting the drought-stress effects on the tested seeds in Norway spruce and Scots pine. However, Douglas fir drought-stressed seeds did not respond positively to the BR treatment. English oak was not subjected to drought-stress, and the germination of the control- and BR-treated acorns did not differ under optimal humidity. Under optimal humidity regime, the effect of BR treatment was positive only in the case of Norway spruce.

\section{Acknowledgements}

This study was supported by the Czech University of Life Sciences Prague (Project No. CIGA 20124304), and the Ministry of Agriculture of the Czech Republic (Project No. QJ1220331). The experiment was conducted in the Seed testing laboratory of the Department of Silviculture at the Truba Research Station (Faculty of Forestry and Wood Science, Czech University of Life Sciences Prague). We thank Jitka Šišáková (Translation and Editing Services, Roztoky u Prahy, Czech Republic), Andrew Leslie (National School of Forestry, Cumbria, UK) and Dr. W. Keith Moser (USDA Forest Service, Rocky Mountain Research Station, USA) for proofreading the manuscript.

\section{References}

Agresti A, Bini M, Bertaccini B, Ryu E (2008). Simultaneous confidence intervals for comparing binomial parameters. Biometrics 64: 12701275. - doi: 10.1111/j.1541-0420.2008.00990.x

Ahammed GJ, Zhang S, Shi K, Zhou Y-H, Yu J-Q (2012). Brassinosteroid improves seed germination and early development of tomato seedling under phenanthrene stress. Plant Growth Regulation 68: 87-96. - doi: 10.1007/s10725-012-969 6-0

Ali SS, Kumar GBS, Khan M, Doohan FM (2013). Brassinosteroid enhances resistance to Fusarium diseases of barley. Phytopathology 103: 1260-1267. - doi: 10.1094/PHYTO-05-13-0111-R

Anuradha S, Rao SSR (2003). Application of brassinosteroids to rice seeds (Oryza sativa L.) reduced the impact of salt stress on growth, prevented photosynthetic pigment loss and increased nitrate reductase activity. Plant Growth Regulation 40: 29-32. - doi: 10.1023/A:10 23080720374

Bajguz A (2007). Metabolism of brassinosteroids in plants. Plant Physiology and Biochemistry 45: 95-107. - doi: 10.1016/j.plaphy.2007.01.002

Bajguz A, Hayat S (2009). Effects of brassinosteroids on the plant responses to environmental stresses. Plant Physiology and Biochemistry 47: 1-8. - doi: 10.1016/j.plaphy.2008.10.002

Bonner FT, Vozzo JA (1987). Seed biology and technology of Quercus. General Technical
Report SO-66, Southern Forest Experiment Station, USDA Forest Service, New Orleans, USA, pp. 21. [online] URL: http://www.srs.fs.usda. gov/pubs/gtr/gtr_soo66.pdf

Clouse SD (2002). Brassinosteroids. The Arabidopsis Book 1: eooog. - doi: 10.1199/tab.0009 CNI (2006). ČSN 481211 Lesní semenářství - Sběr, kvalita a zkoušky kvality semenného materiálu lesních dřevin [Forest Seed Management - Collection, quality and methods for testing forest tree seeds]. Český normalizační institut, Praha, Czech Republic, pp. 60. [in Czech]

Dhaubhadel S, Chaudhary S, Dobinson KF, Krishna $P$ (1999). Treatment with 24-epibrassinolide, a brassinosteroid, increases the basic thermotolerance of Brassica napus and tomato seedlings. Plant Molecular Biology 40: 333-342. - doi: 10.1023/A:1006283015582

Divi UK, Rahman T, Krishna P (2010). Brassinosteroid-mediated stress tolerance in Arabidopsis shows interactions with abscisic acid, ethylene and salicylic acid pathways. BMC Plant Biology 10: 151. - doi: 10.1186/1471-2229-10-151

Edwards DGW, El-Kassaby YA (1995). Douglas-fir genotypic response to seed stratification. Seed Science and Technology 23: 771-778. [online] URL: http://cat.inist.fr/?aModele=afficheN\&cpsi $\mathrm{dt}=3005137$

Gregory LE (1981). Acceleration of plant growth through seed treatment with Brassins. American Journal of Botany 68: 586-588 URL. - doi: $10.2307 / 2443034$

Grove MD, Spencer GF, Rohwedder WK, Mandava N, Worley JF, Warthen Jr JD, Steffens GL, Flippen-Anderson JL, Cook Jr JC (1979). Brassinolide, a plant growth-promoting steroid isolated from Brassica napus pollen. Nature 281: 216-217. - doi: 10.1038/281216ao

Gudesblat GE, Russionova E (2011). Plants grow on brassinosteroids. Current Opinion in Plant Biology 14 (5): 530-537. - doi: 10.1016/j.pbi.2011. 05.004

Himanen K, Nygren M (2014). Effects of seed pre-soaking on the emergence and early growth of containerized Norway spruce seedlings. New Forests 45: 71-82. - doi: 10.1007/s1105 6-013-9392-6

Hoffmann J, Chválová K, Palátová E (2007). Lesné semenárstvo na Slovensku [Forest seed management in Slovakia] (2 ${ }^{\text {nd }}$ edn). IRgamma, Sliač, Slovak Republic, pp. 195. [in Slovak] Houšková K, Martiník A (2015). Does prolonged stratification of Douglas fir influence the yield of seedlings? Journal of Forest Science 61: 268273. - doi: 10.17221/7/2015-JFS

Choudhary PS, Yu J-Q, Yamaguchi-Shinozaki K, Kazuo S, Tran L-SP (2012). Benefits of brassionosteroid crosstalk. Trends in Plant Science 10: 594-605. - doi: 10.1016/j.tplants.2012.05.012 Ikekawa N, Takatsuto S (1984). Microanalysis of brassinosteroids in plants by gas chromatography/mass spectrometry. Mass Spectroscopy 32 (1): 55-70. - doi: 10.5702/massspec.32.55

ISTA (2015). International rules for seed testing. International Seed Testing Association (ISTA), Bassersdorf, Switzerland, pp. 276. - doi: 10.1525 8/istarules.2015.F

Kamra SK, Simak M (1968). Germination studies on Scots pine (Pinus silvestris L.) seed of different provenances under alternating and constant temperatures. Studia Forestalia Suecica
62: 1-14. [online] URL: http://pub.epsilon.slu.se/ 5842/1/SFSo62.pdf

Kartal G, Temel A, Arican E, Gozukirmizi N (2009). Effects of brassinosteroids on barley root growth, antioxidant system and cell division. Plant Growth Regulation 58: 261-267. - doi: 10.1007/s10725-009-9374-z

Kim S-K, Chang SC, Lee EJ, Chung W-S, Kim Y-S, Hwang S, Lee JS (2010). Involvement of brassinosteroids in the gravitropic response of primary root of Maize. Plant Physiology 123: 9971004. - doi: 10.1104/pp.123.3.997

Kohout L, Kasal A, Chodounská H, Slavíková B, Hniličková J (2003). The use of 2a, 3a, 17SS-trihydroxy-5a-androstan-6-one as active ingredient for plant development regulation. Patent International Publication no. WO 03/003834 A1, Application Number PCT/CZ2002/000041, World Intellectual Property Organisation, International Bureau, Geneva, Switzerland, pp. 17.

Krishna P (2003). Brassinosteroid-mediated stress responses. Journal of Plant Growth Regulation 22: 289-297. - doi: 10.1007/s00344-0030058-z

Krugman SL, Jenkinson JL (2008). Pinaceae Pine family Pinus L. Pine. In: “The Woody Plant Seed Manual” (Bonner FT, Karrfalt RP eds). Agricultural Handbook 727, USDA Forest Service, Washington, DC, USA, pp. 809-847.

Leinonen K, Rita H (1995). Interaction of prechilling, temperature, osmotic stress, and light in Picea abies seed germination. Silva Fennica 29: 95-106. - doi: 10.14214/sf.a9200

Leubner-Metzger G (2001). Brassinosteroids and gibberellins promote tobacco seed germination by distinct pathways. Planta 213: 758-763. doi: $10.1007 /$ s004250100542

Li K-R, Wang HH, Han G, Wang QJ, Fan J (2008). Effects of brassinolide on the survival, growth and drought resistance of Robinia pseudoacacia seedlings under water-stress. New Forests 35: 255-266. - doi: 10.1007/s11056-007-9075-2

Li K-R, Zhang S, He X (2002). Effect of natural brassinolide on germination of Pinus tabulaeformis and Robinia pseudoacacia seeds. Scientia Silvae Sinicae 38: 150-153. [online] URL: http:// en.cnki.com.cn/Article_en/CJFDTOTAL-LYKE200 206024.htm

Li K-R, Zhang W-B, Li H-K (2005). Effect of natural brassinolide on germination of Ailanthus altissima seeds. Forestry Studies in China 7: 12-14. - doi: 10.1007/s11632-005-0014-z

Liu Y, Kermode A, El-Kassaby YA (2013). The role of moist-chilling and thermo-priming on the germination characteristics of white spruce (Picea glauca) seed. Seed Science and Technology 41 (3): 321-335. - doi: 10.15258/sst.2013.41. 3.01

Maguire JD (1962). Speed of germination - aid in selection and evaluation for seedling emergence and vigor. Crop Science 2: 176-177. - doi: 10.2135/cropsci1962.0011183X000200020033X Müssig C, Lisso J, Coll-Garcia D, Altmann T (2005). Molecular analysis of brassinosteroid action. Plant Biology 8: 291-296. - doi: 10.1055/s2005-873043

Nowakowska J, Rakowski K (2002). Accelerated and natural ageing processes change the properties of plasma membrane in Norway spruce (Picea abies [L.] Karst.) seeds during storage. Dendrobiology 47: 79-82. [online] URL: http:// 
agro.icm.edu.pl/agro/element/bwmeta1.eleme nt.agro-article-5a3c0525-afee-402d-b698-

478dgee322c4

O'Reilly C, Doody P (2006). Reaping what you sow - seeds and plant quality. In: Proceedings of the COFORD Conference "Plant quality: a key to success in forest establishment" (MacLennan L, Fennessy J eds). Tullow, Co Carlow (Irish Republic), 20-21 Sep 2005, pp. 11-20. [online] URL: http://www.forestry.gov.uk/pdf/ CofordPlantQuality.pdf/\$FILE/CofordPlantQuali ty.pdf\#page $=17$

Podrázský V, Zahradník D, Remeš J (2014). Potential consequences of tree species and age structure changes in the Czech Republic review of forest inventory data. Wood Research 59: 483-490. URL. [online] URL: http://www.centrumdp.sk/wr/03/11.pdf

Remeš J, Zeidler A (2014). Production potential and wood quality of Douglas fir from selected sites in the Czech Republic. Wood Research 59: 509-520. [online] URL: http://www.centrumdp. sk/wr/03/14.pdf

Rönsch GA, Matschke J, Schachler G (1993). Influence of (22S,23S)-homobrassinolide on rooting capacity and survival of adult Norway spruce cuttings Tree Physiology 12: 71-80. - doi: 10.1093/treephys/12.1.71

Sairam RK (1994). Effects of homobrassinolide application on plant metabolism and grain yield under irrigated and moisture-stress conditions of two wheat varieties. Plant Growth Regulation 14: 173-181. - doi: 10.1007/BF00025220

Sasse JM (1997). Recent progress in brassinosteroid research. Physiologia Plantarum 100: 696-701. - doi: 10.1111/j.1399-3054.1997.tb0307 $6 . x$

Srivastava K, Raghava N, Shagun B, Raghava P (2011). Brassinosteroids stimulate seed germination parameters and chlorophyll content in mongobean. Indian Journal of Scientific Research 2: 89-92. [online] URL: http://www.ijsr. in/upload/2060292468Chapter

Steber CM, McCourt P (2001). A role for brassinosteroids in germination in Arabidopsis. Plant Physiology 125: 763-769. - doi: 10.1104/pp.125.2.7 63

Suszka B, Muller C, Bonnet-Masimbert M (1996). Seeds of forest broadleaves-from harvest to sowing. INRA, Paris, France, pp. 294. [online] URL: http://books.google.com/books?id=ujkIA IbxWG4C

Vardhini BV, Rao SSR (2003). Amelioration of osmotic stress by brassinosteroids on seed germination and seedling growth of three varieties of sorghum. Plant Growth Regulation 41: 25-31. - doi: 10.1023/A:1027303518467

Wang B, Zhang J, Xia X, Zhang W-H (2011). Ameliorative effect of brassinosteroid and ethylene on germination of cucumber seeds in the presence of sodium chloride. Plant Growth Regulation 65: 407-413. - doi: 10.1007/s10725-011-9595-
9

Wang Z-Y (2012). Brassinosteroids modulate plant immunity at multiple levels. Proceedings of the National Academy of Sciences USA 109: 7-8. - doi: 10.1073/pnas.1118600109

Wilen R, Sacco M, Gusta LV, Krishna P (1995). Effects of 24-epibrassinolide on freezing and thermotolerance of bromegrass (Bromus inermis) cell cultures. Physiologia Plantarum 95: 195-202. - doi: 10.1111/j.1399-3054.1995.tboo82 $7 . \mathrm{x}$

Yamaguchi T, Wakizuka T, Hirai K, Fujii S, Fujita A (1987). Stimulation of germination in aged rice seeds by pretreatment with brassinolide. Proceeding of Plant Growth Regulation Society of America 14: 26-27.

Yokota T, Arima M, Takahashi N (1982). Castasterone, a new phytosterol with plant-hormone potency, from chestnut insect gall. Tetrahedron Letters 23: 1275-1278. - doi: 10.1016/So0404039(00)87081-1

Youngblood A, Safford LO (2008). Pinaceae-Pine family Picea A. Dietr. spruce. In: "The Woody Plant Seed Manual" (Bonner FT, Karrfalt RP eds). USDA Forest Service, Washington, DC, USA, pp. 793-806.

Zullo MAT, Kohout L (2004). Semisystematic nomenclature of brassinosteroids. Plant Growth Regulation 42: 15-28. - doi: 10.1023/B:GROW.000 0014898.30414 .33 